\title{
The Impact of Music, Song and Movements on the Language Acquisition by Preschool Children between the Ages of 48-60 Months
}

\author{
Tuğluk. Mehmet Nur, Mertoğlu. Ercan and Kuzucu. F. Buşra*
}

\begin{abstract}
This research investigated the effectiveness of music along with physical movement in terms of English Language Acquisition of 48-60 month old young learners in the preschool education. To realise this aim, a quantitative study and experimental research design randomized pre-test, post-test with control group design was carried out in a public preschool in Istanbul, Turkey. Two instruments named "Rhythm Performance Observation Form" and "Vocabulary Performance Checklist" were used to collect the data and comparisons were made to find out whether rhythm and educational English music associated with physical activities could improve achievements in English. The results indicated that rhythm and English music combined with physical activities increase the level of children's language development more than flashcards. It is hoped that future research continues exploring the ways of how English music can be taken seriously in the acquiring of English to children in their early years under the Pre-school Education Program.
\end{abstract}

Index Terms - English music, language acquisition, rhythm, very young learner.

\section{INTRODUCTION}

Music is essential and very relaxing for everyone particularly for children as they respond enthusiastically to songs and welcome them as it is an essential part of the human experience [1].

The aim of this research is to investigate the effectiveness of music along with physical movement in terms of English Language Acquisition of 48-60 month old young learners in the preschool education. With regards to the aim the research questions are as follows;

1) Is there a significant difference between the scores of the research group and the control in terms of the rhythm skills, the recipient language and the expressive language performance. This is done with the help of rhythm and English music and movements combined with the words in the song for 48-60 months old young learners in the preschool education?

Based on the researcher questions, the study shows significant differences between between the scores of the children in the research group and control group.

It is not new that music and songs have been used as a Turkey

*Kuzucu. F. Buşra is with the Master Stdent, Yıldız Technical University, teaching tool. Recently, more studies show that music help strengths and consolidate in the areas of developments and skills such as language acquiring, rhvme and rhythm, coordination of movement and equilibrium for 0-6 aged children. Toscano-Fuentes (2010), for instance, stated that there is a connection language skills of language learners with respect to foreign language and their musical intelligence. In a study $\mathrm{Li}$ and Brand (2009) found that children's language development increased dramatically with the help of music and song compare to others. Schwarz (2012), it was also found that the children were good at acquiring vocabulary by listening English songs in their daily life [2].

The Rhythm Performance Observation Form created by Dr. Instructor Ercan Mertoğlu has also been used in previous researchers [3], [4], [5], [6]. According to the findings of the researches, it was found that there were differences in rhythmic performance differences among children, in children's rhythmic performance skill and other skill areas; intuitive math skills, reasoning skills, and cognitive skills. It has also been found in the experimental studies in which the Rhythm Performance Observation Form was used, it was effective in measuring the development of the rhythm sense.

In Turkey, not much attention is given helping young learners to acquire the language. It is well known that Montessori Method also encourages language acquisition through rhvmes and songs. Another teaching technique that recently gained fame is the Kagan Approach. This Approach is using music and movement to teach English for instance, there are games like "Mirror Mirror" in which children work in pairs. One partner does musical movement and the other partner imitates. Similarly, for vocabulary and concept acquisition in young learners it needs to be identified the extent to which preschool children can productively acquire rhythm skills and language based on songs and musical activities.

\section{A. Language Acquisition and Young Learners}

A child is born, he subconsciously starts to absorb the language from the people in the environment. From zero to three years of age, according to Montessori, the child is in unconscious stage of language acquisition. This means that the child is involuntarily acquiring language in terms of vocabulary and understanding the emotion behind words such as a smile shows happiness and frown means sadness. Three to six years of age child enters the conscious absorbent mind stage. Here the child becomes aware that words have meanings. Now the child 
starts to learn the basic sentence structure and is able to communicate his needs.

If a child is exposed to another language at this age, it is highly likely that he will be able speak the second language like a native speaker. This is because the child is in the sensitive period for language between the ages of three to six years. By sensitive period it is meant that the child experiencing and extraordinary urge to acquire the language. If this urge is not catered to at the right time and the sensitive period passes away, the child will never be able to acquire the language as easily and accurately as he could have during the sensitive period.

\section{B. Music and Song in Language Acquisition}

Chen-Hafteck (1997: 85) state that Music and language are the two ways that humans communicate and express themselves through sound. Since birth, babies start to listen and produce sound without distinguishing between music and language, singing and speech [7].

It is also discovered that young learners tend to change their mood more frequently than adults and children find it difficult to sit still and concentrate for a long period of time [1]. Hence, it is very important to use a method that motivate the children, appeals to their internal instinct. This basic instinct is the need for movement, language and social interaction.

Through well-planned musical activities young learners can acquire and practice vocabulary and phrases and sentence structures. To motivate the YLs, opportunities are provided for physical movement and experiencing the language through the music. Children are able to acquire language unconsciously without even understanding the meaning through words rather they understand the meaning of the words through action and movements as the they mime the lyrics of the song [8].

\section{METHOD}

\section{A. Participants}

There were 44 children who participated in the study. 21 were in the control group and 23 in the research group. These children were between the ages of 48-60 months old young learners in the preschool education, from a public school in Istanbul, Turkey. None of them had previously been given English language.

\section{B. Measures}

Two instruments used were:

\section{a. "Rhythm Performance Observation Form"}

It was designed by one of the authors, Ercan Mertoğlu, and included twelve different rhythm patterns.

\section{b. "Vocabulary Performance Checklist"}

It was designed by researchers and included 33 English language items which were used to collect the data. Songs used for this research were chosen in accordance with the target words, rhythm patterns and Total Physical Response (TPR) that was used as technique during activities.

\section{Design of the Study}

The research was a quantitative study and had an experimental research design randomized pre-test, post-test with control group design as in Table I.

TABLE I: EXPERIMENTAL PATTERN MODEL WITH PRETEST-POSTTEST CONTROL GROUP

\begin{tabular}{|lcccc|}
\hline Group & Pretest & Practice & Posttest & Retention test \\
\hline Research group & O1 & X1 & O3 & O5 \\
Control group & O2 & X2 & O4 & --- \\
\hline
\end{tabular}

In Table I, O1 and O2 indicate pre-test application; O3 and $\mathrm{O} 4$ represent post-test application; $\mathrm{O} 5$ refers to the retention test only for the research group. X1 shows independent variables (English songs and musical games) applied to the subjects in the research group and X2 shows independent variables (flash cards) applied to the subjects in the control group [9]. Comparisons were made to find out whether rhythm and educational English music associated with physical activities could improve achievements in English.

In the research group, rhythm and English action songs were used to achieve target English words and concepts. On the other hand, the control group did not receive rhythm and English music, instead flash cards expressing the target English words and concepts were given as shown in Table II.

\begin{tabular}{|c|c|c|c|c|}
\hline Group & Pretest & Practice & Posttest & Retention \\
\hline $\begin{array}{l}\text { Research } \\
\text { group }\end{array}$ & $\begin{array}{l}\text { 1.Vocabulary } \\
\text { Performance } \\
\text { Checklist } \\
\text { 2. Rhythm } \\
\text { Performance } \\
\text { Observation } \\
\text { Form }\end{array}$ & $\begin{array}{l}\text { 1.Flash } \\
\text { Cards } \\
\text { 2. English } \\
\text { music and } \\
\text { Songs } \\
\text { 3.Rhythm }\end{array}$ & $\begin{array}{l}\text { 1.Vocabulary } \\
\text { Performance } \\
\text { Checklist } \\
\text { 2. Rhythm } \\
\text { Performance } \\
\text { Observation } \\
\text { Form }\end{array}$ & $\begin{array}{l}\text { 1.Vocabulary } \\
\text { Performance } \\
\text { Checklist } \\
\text { 2. Rhythm } \\
\text { Performance } \\
\text { Observation } \\
\text { Form }\end{array}$ \\
\hline $\begin{array}{l}\text { Control } \\
\text { group }\end{array}$ & $\begin{array}{l}\text { 1.Vocabulary } \\
\text { Performance } \\
\text { Checklist } \\
\text { 2. Rhythm } \\
\text { Performance } \\
\text { Observation } \\
\text { Form }\end{array}$ & & $\begin{array}{l}\text { 1.Vocabulary } \\
\text { Performance } \\
\text { Checklist } \\
\text { 2. Rhythm } \\
\text { Performance } \\
\text { Observation } \\
\text { Form }\end{array}$ & \\
\hline
\end{tabular}

\section{Procedure}

In general terms, the children tapped rhythms which matched the vocabulary within the song. Then young learners (YL) listened to related video- songs, and did commands in the video, imitating non-verbal responses such as "wash your face", "clap your hands", "brush your teeth", or "shake your legs" with the help of Total Physical Response (TPR) method. In addition, within the song and rhythm practices, more emphasis was placed on language acquisition through words and concepts.

Regarding an activity plan, as a pre-listening activity, target words were given through flashcards to introduce new language items and vocabulary within the song to both groups. Control group was taught the language only with this step.

In the second stage, each target word and concept was practiced by tapping related rhythm with the help of hands or a pencil helped children to understand how to spell and pronounce English words. In the third stage-listening session, song was heard and videos with mimes were watched. The 
second time, song was heard again but this time children mime the action. Additionally, some children automatically started to mimic the lyrics of the song. The song was played repetitively for the children to listen and copy the actions. At this age, the children have tendency for repetition by repeating the activity many times they master the skill. After all, practice makes perfect.

After the listening and movement session, rhythms were tapped simultaneously with chanting, that is, one child say the word and the rest of the children tapped the rhythm. Altogether, the target song-video was played 5 to 7 times during one session of the class or as much as the children like to listen to.

\section{E. Data Analysis}

From the point of English Language Acquisition, comparisons were made between scores of the control group and the research group based on rhythm and educational English music associated with physical activities. Within each group, comparisons were also made regarding the development of receptive language, expressive language and rhythm skills. The data collected was analyzed with Shapiro-Wilk analysis, Mann-Whitney U Test and Wilcoxon Signed Ranks Test.

\section{RESULTS AND FINDINGS}

In this section, the results of analysis and findings are given in table form in the light of the the sub problems of the study as follows;

1) Is there a significant difference between pre-test of the rhythm, the recipient language and the expressive language scores of the English Language Acquisition of the 48-60 month-old children in the research and control groups?

The Results of Mann-Whitney U Test which was used as a pre-test show values as rhythm $\mathrm{U}=205,00, \mathrm{p}=, 388>, 05$; the recipient language $U=204,00, p=, 370>, 05$ and the expressive language $\mathrm{U}=211,00, \mathrm{p}=, 371>, 05$, which were not smaller than 0.05 . Thus, there was not a statistically significant difference between the experimental group and the control group in Vocabulary Performance Checklist and Rhythm Performance Observation Form. This indicates that both group level of English is the same (Table III).

TABLE III: MANN-WhitNEy U TEST RESUlTS FOR RHYTHM, RECEPTIVE LANGUAGE, AND EXPRESSIVE LANGUAGE PRE-TEST SCORES OF CHILDREN IN THE RESEARCH AND CONTROL

\begin{tabular}{|l|l|l|l|l|l|l|l|l|}
\hline Pre-test & Group & $\mathrm{N}$ & $\bar{X}$ & $\mathrm{~S}$ & $\begin{array}{l}\text { Mean } \\
\text { Rank }\end{array}$ & $\begin{array}{l}\text { Sum of } \\
\text { Ranks }\end{array}$ & $\mathrm{U}$ & $\mathrm{p}$ \\
\hline Rhythm & $\begin{array}{l}\text { Research } \\
\text { Control }\end{array}$ & 23 & 6,39 & 3,54 & 20,91 & $\begin{array}{l}481,00 \\
509,00\end{array}$ & $\begin{array}{l}205,0 \\
0\end{array}$ &, 388 \\
& 21 & 7,33 & 2,24 & 24,24 & & \\
\hline $\begin{array}{l}\text { Recipient } \\
\text { language }\end{array}$ & Research & 23 & 5,48 & 3,33 & 20,87 & 480,00 & $\begin{array}{l}204,0 \\
0\end{array}$ &, 370 \\
& Control & 21 & 6,05 & 1,53 & 24,29 & 510,00 & & \\
\hline $\begin{array}{l}\text { Expressive } \\
\text { language }\end{array}$ & Research & 23 & 0,61 & 1,16 & 23,83 & $\begin{array}{l}548,00 \\
21,05\end{array}$ & $\begin{array}{l}211,0 \\
0\end{array}$ &, 371 \\
& Control & 21 & 0,29 & 0,56 & 21,05 & & \\
\hline
\end{tabular}

$* \mathrm{p}<, 05$

2)Is there a significant difference between the scores of the research group's Rhythm Performance Observation Form" and "Vocabulary Performance Checklist" for rhythm, the recipient language and the expressive language scores of the 48-60 month-old children in the research and control groups?

The Results of Mann-Whitney U Test which was used as a post-test show values as rhythm $\mathrm{U}=154,50, \mathrm{p}=, 039<, 05$; the recipient language $\mathrm{U}=66,50, \mathrm{p}=, 000<, 05$ and the expressive language $\mathrm{U}=100,00, \mathrm{p}=, 001<, 05$ of two groups, which were smaller than 0.05. Thus, it is concluded that there is a statistically significant difference based on values in favour of research group in the post-test scores (Table 4).

TABLE IV: MANN-WhitNEy U TEST RESULTS FOR RHYTHM, RECEPTIVE LANGUAGE, AND EXPRESSIVE LANGUAGE POST-TEST SCORES OF CHILDREN IN THE RESEARCH AND CONTROL GROUPS

\begin{tabular}{|l|l|l|l|l|l|l|l|l|}
\hline Post-test & Group & $\mathrm{N}$ & $\bar{X}$ & $\mathrm{~S}$ & $\begin{array}{l}\text { Mean } \\
\text { Rank }\end{array}$ & $\begin{array}{l}\text { Sum of } \\
\text { Ranks }\end{array}$ & $\mathrm{U}$ & $\mathrm{p}$ \\
\hline Rhythm & Experimental & 23 & 10,00 & 1,73 & 26,28 & 604,50 & 154,5 &, $039^{*}$ \\
& Control & 21 & 8,4 & 3,05 & 18,36 & 385,50 & 0 & \\
\hline $\begin{array}{l}\text { Recipient } \\
\text { language }\end{array}$ & Experimental & 23 & 22,04 & 4,84 & 30,11 & 692,50 & 204,0 &, $000^{*}$ \\
& Control & 21 & 15,71 & 3,55 & 14,17 & 297,50 & 0 & \\
\hline $\begin{array}{l}\text { Expressive } \\
\text { language }\end{array}$ & Experimental & 23 & 11,35 & 5,38 & 28,65 & 659,00 & 211,0 &, $001^{*}$ \\
& Control & 21 & 5,81 & 4,70 & 15,76 & 331,00 & 0 & \\
\hline
\end{tabular}

${ }^{*} \mathrm{p}<, 05$

According to Table IV, it is indicated that rhythm and English music combined with physical activities increase the level of children's language development more than using flashcards.

3) Is there a significant difference between the pre-test and post-test score differences of the two groups, the control and research group for rhythm the recipient language and the expressive language?

The Results of Mann-Whitney U Test in which both groups' scores was calculated and compared show values as rhythm $\mathrm{U}=153,00, \mathrm{p}=, 036<, 05$; the recipient language $\mathrm{U}=84,50$, $\mathrm{p}=, 000<, 05$ and the expressive language $\mathrm{U}=99,50, \mathrm{p}=, 001<, 05$ (Table V)

TABLE V: MANN-WhitNey U TEST RESUlts REgaRding THE DIFFERENCE BETWEEN PRE-TEST AND POST-TEST SCORES FOR RHYTHM, RECIPIENT LANGUAGE AND THE EXPRESSIVE LANGUAGE IN THE RESEARCH

\begin{tabular}{|l|l|l|l|c|c|c|l|l|}
\hline $\begin{array}{l}\text { Control } \\
\text { Group }\end{array}$ & Test & N & $\bar{X}$ & S & Mean Rank & $\begin{array}{c}\text { Sum of } \\
\text { Ranks }\end{array}$ & Z & P \\
\hline Rhythm & Pre-test & 21 & 7,33 & 2,24 & 8,67 & 52,00 & $-1,17$ &, $243^{*}$ \\
& Post-test & 21 & 8,14 & 3,05 & 9,18 & 101,00 & & \\
\hline $\begin{array}{l}\text { Recipient } \\
\text { language }\end{array}$ & Pre-test & 21 & 6,05 & 1,53 &, 00 &, 00 & $-4,02$ &, $000^{*}$ \\
\hline Post-test & 21 & 15,71 & 3,55 & 11,00 & 231,00 & & \\
langressive & Pre-test & 21 & 0,29 & 0,56 &, 00 &, 00 & $-3,93$ &, $000^{*}$ \\
& Post-test & 21 & 5,81 & 4,70 & 12,00 & 210,50 & & \\
\hline
\end{tabular}

$* \mathrm{p}<, 05$

In the light of values given Table $\mathrm{V}$, it is indicated that language development took placed more in the research group which were given the language with rhythm and English music combined with physical activities than control group were taught the language by using flashcards.

4) Is there a significant difference between the scores of pre-test and the post-test for rhythm, the recipient language and the expressive language of the children aged 48-60 months in the research group?

The Results of Wilcoxon Signed Ranks Test which was used to compare the scores of pre-test and post-test show as rhythm $\mathrm{Z}=-3,54, \quad \mathrm{p}=, 000<, 05 ; \quad$ the recipient language $\mathrm{Z}=-4,20$, 
$\mathrm{p}=, 000<, 05$ and the expressive language $\mathrm{Z}=-4,20, \mathrm{p}=, 000<, 05$ (Table6).

TABLE VI: WiLCOXON Signed RANKS TEST RESULTS REgARDING THE DIFFERENCE BETWEEN PRE-TEST AND POST-TEST SCORES FOR RHYTHM, RECIPIENT LANGUAGE AND THE EXPRESSIVE LANGUAGE IN THE RESEARCH

\begin{tabular}{|c|c|c|c|c|c|c|c|c|}
\hline $\begin{array}{c}\text { Research } \\
\text { Group }\end{array}$ & Test & $\mathrm{N}$ & $\bar{X}$ & $\mathrm{~S}$ & $\begin{array}{c}\text { Mean } \\
\text { Rank }\end{array}$ & $\begin{array}{c}\text { Sum of } \\
\text { Ranks }\end{array}$ & $\mathrm{Z}$ & $\mathrm{p}$ \\
\hline Rhythm & Pre-test & 23 & 6,39 & 3,54 & 5,50 & 22,00 & $-3,54$ &, $000^{*}$ \\
& Post-test & 23 & 10,00 & 1,73 & 13,37 & 254,00 & & \\
\hline Recipient & Pre-test & 23 & 5,48 & 3,33 &, 00 &, 00 & $-4,20$ &, $000^{*}$ \\
language & Post-test & 23 & 22,04 & 4,84 & 12,00 & 276,00 & & \\
\hline Expressive & Pre-test & 23 & 0,61 & 1,16 &, 00 &, 00 & $-4,20$ &, $000^{*}$ \\
language & Post-test & 23 & 11,35 & 5,38 & 12,00 & 276,00 & & \\
\hline
\end{tabular}

$* \mathrm{p}<, 05$

As seen in Table VI, to compare to pre-test and post-test scores, there is significant development of language and rhythm skills in the research group. Therefore, it is indicated that rhythm and English music combined with physical activities increase the level of children's language development more than flashcards.

5) Is there a significant difference between the scores of pre-test and the post-test for rhythm, the recipient language and the expressive language of the children aged 48-60 months in the control group?

The Results of Wilcoxon Signed Ranks Test which was used to compare the scores of pre-test and post-test show as rhythm $\mathrm{Z}=-1,17, \quad \mathrm{p}=, 243>, 05$; the recipient language $\mathrm{Z}=-4,02$, $\mathrm{p}=, 000<, 05$ and the expressive language $\mathrm{Z}=-3,93, \mathrm{p}=, 000<, 05$ (Table VII).

TABLE VII: WILCOXON SIgNED RANKS TEST RESULTS REgaRding the DiFFERENCE BETWEEN PRE-TEST AND POST-TEST SCORES FOR RHYTHM, RECIPIENT LANGUAGE AND THE EXPRESSIVE LANGUAGE IN THE CONTROL

\begin{tabular}{|c|c|c|c|c|c|c|c|c|}
\hline \multicolumn{9}{|c|}{ GROUP } \\
\hline $\begin{array}{l}\text { Difference } \\
\text { Between Pre- } \\
\text { test, Post-test }\end{array}$ & Group & $\mathrm{N}$ & $\bar{x}$ & $\mathrm{~s}$ & $\begin{array}{l}\text { Mean } \\
\text { Rank }\end{array}$ & $\begin{array}{l}\text { Sum of } \\
\text { Ranks }\end{array}$ & $\mathrm{U}$ & p \\
\hline Rhythm & $\begin{array}{l}\text { Research } \\
\text { Control }\end{array}$ & $\begin{array}{l}23 \\
21\end{array}$ & $\begin{array}{l}3,61 \\
0,81\end{array}$ & $\begin{array}{l}3,82 \\
3,68\end{array}$ & $\begin{array}{l}26,35 \\
18,29\end{array}$ & $\begin{array}{l}606,00 \\
384,00\end{array}$ & 153,00 & $.036^{\circ}$ \\
\hline $\begin{array}{l}\text { Recipient } \\
\text { language }\end{array}$ & $\begin{array}{c}\text { Research } \\
\text { Control }\end{array}$ & $\begin{array}{l}23 \\
21\end{array}$ & $\begin{array}{c}16,57 \\
9,67\end{array}$ & $\begin{array}{l}6,19 \\
3,94\end{array}$ & $\begin{array}{l}29,33 \\
15,02\end{array}$ & $\begin{array}{l}674,50 \\
315,50\end{array}$ & 84,50 & $.000^{\circ}$ \\
\hline $\begin{array}{l}\text { Expressive } \\
\text { language }\end{array}$ & $\begin{array}{c}\text { Research } \\
\text { Control }\end{array}$ & $\begin{array}{l}23 \\
21\end{array}$ & $\begin{array}{c}10,74 \\
5,52\end{array}$ & $\begin{array}{l}4,92 \\
4,70\end{array}$ & $\begin{array}{l}28,67 \\
15,74\end{array}$ & $\begin{array}{l}659,50 \\
330,50\end{array}$ & 99,50 &, $001^{*}$ \\
\hline
\end{tabular}

As seen in Table VII, the comparison of pre-test and post-test scores, there is development of language in the control group. However, the score of research group is higher than the score of the control group. Thus, it is indicated that rhythm and English music combined with physical activities increase the level of children's language development more than flashcards.

6) Is there a significant difference between the scores of the post-test and retention test of rhythm, the recipient language and the expressive language of the children aged 48-60 months in the control group?

The Results of Wilcoxon Signed Ranks Test which was used to compare values of post-test and retention test show as rhythm $\mathrm{Z}=-1,76, \quad \mathrm{p}=, 078>, 05$; the recipient language $\mathrm{Z}=-1,92$, $\mathrm{p}=, 055>, 05$ and the expressive language $\mathrm{Z}=-1,75, \mathrm{p}=, 080>, 05$ (Table VIII).
TABLE VIII: WILCOXON SIGNED RANKS TEST RESULTS REGARDING THE DIFFERENCE BETWEEN POST-TEST AND RETENTION TEST SCORES FOR RHYTHM, RECIPIENT LANGUAGE AND THE EXPRESSIVE LANGUAGE IN THE RESEARCH GROUP

\begin{tabular}{|c|c|c|c|c|c|c|c|c|}
\hline $\begin{array}{l}\text { Research } \\
\text { Group }\end{array}$ & Test & $\mathrm{N}$ & $\bar{X}$ & $\mathrm{~S}$ & $\begin{array}{l}\text { Mean } \\
\text { Rank }\end{array}$ & $\begin{array}{c}\text { Sum of } \\
\text { Ranks }\end{array}$ & Z & $\mathrm{p}$ \\
\hline \multirow[t]{2}{*}{ Rhythm } & Post-test & 23 & 10,00 & 1,73 & \multirow[b]{2}{*}{$\begin{array}{l}8,83 \\
7,14\end{array}$} & 26,50 & \multirow[t]{2}{*}{$-1,76$} & \multirow[t]{2}{*}{, 078} \\
\hline & $\begin{array}{l}\text { Retention } \\
\text { test }\end{array}$ & 23 & 10,35 & 1,72 & & 78,50 & & \\
\hline \multirow{2}{*}{$\begin{array}{l}\text { Recipient } \\
\text { language }\end{array}$} & Pre-test & 23 & 22,04 & 4,84 & 9.81 & 127,50 & \multirow[t]{2}{*}{$-1,92$} & \multirow[t]{2}{*}{, 055} \\
\hline & $\begin{array}{c}\text { Retention } \\
\text { test }\end{array}$ & 23 & 21,35 & 4,49 & 8,70 & 43,50 & & \\
\hline \multirow{2}{*}{$\begin{array}{l}\text { Expressive } \\
\text { language }\end{array}$} & Pre-test & 23 & 11,35 & 5,38 & 8,46 & 101,50 & \multirow[t]{2}{*}{$-1,75$} & \multirow[t]{2}{*}{, 080} \\
\hline & $\begin{array}{c}\text { Retention } \\
\text { test }\end{array}$ & 23 & 9,74 & 3,44 & 8,63 & 34,50 & & \\
\hline
\end{tabular}

It is evident from the values in Table VIII, that permanence of the acquired words and concepts in English was provided in accordance with rhythm, the recipient language and the expressive language with the help of rhythm and English songs, music and movements in the research group.

\section{CONCLUSION}

Upon understanding the significant effectiveness of the rhythm and English music combined with physical activities, the acquisition process of children aged between 48-60months, it can be concluded that teachers should use more songs and English music in their classroom. Moreover, songs should be used according to the aim of the target language for very young learners. Last but not least, English Language Acquisition ought to be given to children in their early years under the Pre-school Education Program."

\section{REFERENCES}

[1] Şevik. M, Teaching Listening Skills to Young Learners through "Listen and Do" Songs. English Teaching Forum. no. 3, pp. 10-17, 2012

[2] Y. Coyl, R. G. Remei, "Using songs to enhance L2 vocabulary acquisition in preschool children," ELT Journal, vol. 68/3, pp. 276-285, July 2014. http://eltj.oxfordjournals.org

[3] J. Choi, “ 5-6 Yaş Cocuklarına Yönelik Hazırlanan Ritim Eğitimi Programının Çocukta Ritim Duyusunun Gelişimine Etkisinin İncelenmesi,” M. S. thesis, Dept. Edu. Preschool, Marmara Univ., Istanbul, Turkey, 2007.

[4] E. Mertoğlu, "Okul Öncesi Eğitim Kurumlarına Devam Eden 5-6 Yaş Grubundaki Çocukların Ritim Algılamalarının İncelenmesi” Ph.D. dissertation, Dept. Social Studies, Istanbul Univ., Istanbul, Turkey, 2002.

[5] E. Mertoğlu, "A Study on the Relationship Between the Rhythm and Mathematics Skills of 5-6 year old Children," Gifted Education International, ed. Belle Wallace, pp. 26- 44, vol. 26, England, 2010. https://doi.org/10.1177/026142941002600105

[6] B. Özkale, "Ritim Çalışmalarının Altı Yaş Çocuklarının Bilişsel Becerilerine Etkisini," M. S. thesis, Dept. Edu. Preschool, Marmara Univ., Istanbul, Turkey, 2010.

[7] D. Engh, "Why Use Music in English Language Learning? A Survey of the Literature," English Language Teaching, Published by Canadian Center of Science and Education, vol. 6, no. 2, pp. 113-127, 2013. https://doi.org/10.5539/elt.v6n2p113

[8] N. Achkasova, "The Best Ways of Teaching English to Children: Using Children's Operas in Teaching to 5- to 6- Year-Old Children" David Publishing, US-China Education Review A, vol. 3, no. 6, pp. 385-390, June 2013.

[9] Ş. Büyüköztürk, Deneysel desenler öntest-sontest kontrol gruplu desen ve veri analizi, 2st published, Ankara: Pegem, 2007, pp. 21. 
Abbreviations and Acronyms

Language 2: Second Language refers meaning is as another language rather than mother tongue that is being used inside and out of the school for real life purposes

Very Young Learner: The term refers to children 3-6 year old who are at concrete stage and don't know writing or reading.

Total Pysical Response : Do command given by someone and not required learner speak, instead let them be silent, but do the action by following imperatives.

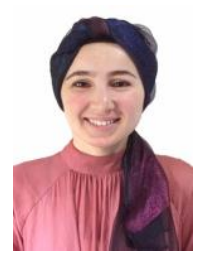

F. B. KUZUCU

10.02.10987 Ankara-Turkey

MA Degree, Social Studies, Education Department, Preschool, Yildiz Technical University,

Istanbul-Turkey

BA, English Language Teaching, Education Department, Uludağ University, 2014, Bursa-Turkey

2017- English Teacher, Palet Schools. Istanbul-Turkey.

2016-2017 English Teacher, Yıldı Technical University, Istanbul-Turkey.

2014-2015 English Teacher, Lazuradi Cordova School, Jakarta- Indonesia. 